\title{
PENGEMBANGAN PEMBELAJARAN BERDASARKAN MASALAH PADA MATA KULIAH KIMIA UNTUK MENINGKATKAN PENGUASAAN KONSEP MAHASISWA
}

\author{
Melania Priska ${ }^{1 *}$, Natalia Peni² ${ }^{2}$ Ludovicus Carvallo ${ }^{3}$, Agnes Pendy $^{4}$ \\ ${ }_{1}^{1}$ Pendidikan Biologi, Universitas Flores, Ende, Indonesia \\ 2,3,4 Pendidikan Matematika, Universitas Flores, Ende, Indonesia
}

\section{A R T I C L E I N F 0}

Article history:

Received 9 Agustus 2020

Received in revised form 14

September 2020 Accepted

25 September 2020

Available online 2 Oktober 2020

Kata Kunci:

Pengembangan,

Penguasaan Konsep,

Pembelajaran Berdasarkan

Masalah,

Keywords

Development,

Mastery of Concepts,

Problem Based Learning,

Solution.

\begin{abstract}
A B S T R A K
Penelitian ini bertujuan untuk marginalizes pengembangan pembelajaran berdasarkan masalah pada mata kuliah kimia untuk meningkatkan penguasaan konsep mahasiswa. Jenis penelitian adalah pengembangan dengan nonequivalent control group design. Sampel dalam penelitian adalah mahasiswa Program Studi Pendidikan Biologi semester 2. Teknik pengumpulan data yang digunakan adalah tes penguasaan konsep. Data diolah dan dianalisis dengan menggunakan uji normalitas, uji homogenitas, dan uji-t. Hasil menunjukkan bahwa nilai signifikansi uji normalitas dan uji homogenitas $>0,05$, dan nilai signifikansi uji-t $<0,05$. Hal ini membuktikan pengembangan pembelajaran berdasarkan masalah dapat meningkatkan penguasaan konsep mahasiswa pada mata kuliah kimia materi larutan.
\end{abstract}

\begin{abstract}
This study aims to analyze the development of learning based on problems in chemistry courses to improve students' mastery of concepts. This type of research is development with a nonequivalent control group design. The sample in this study were students of Biology Education Study Program semester 2, Faculty of Teacher Training and Education, University of Flores. The data collection technique used was a concept mastery test. The data were processed and analyzed using the normality test, homogeneity test, and t-test. The results show that the significance value of the normality test and homogeneity test> 0.05 , and the significance value of the t-test $<0.05$. This proves that the development of problem-based learning can improve students' mastery of concepts in chemistry subject matter solution.
\end{abstract}

\section{Pendahuluan}

Pembelajaran adalah proses interaksi antara siswa dengan sumber belajar. Adanya interaksi yang optimal antara peserta didik dengan sumber belajarnya akan mengujudkan tujuan pembelajaran. Hidayat \& Syafe'i, (2018) menyatakan bahwa keberhasilan pembelajaran dapat mewujudkan tujuan pembelajaran. pembelajaran yang bagaimana yang harusnya dilakukan, tentunya pembelajaran yang bisa mengembangkan hubungan interaksi antara peserta didik dan sumber belajar serta pembelajaran yang bisa membuat siswa menemukan, menggali dan membangun pengetahuannya sendiri. Pembelajaran yang membuat siswa belajar adalah pembelajaran yang sesuai dengan paham konduktivitas. Pembelajaran konstruktivistik menekankan pada peran mahasiswa untuk mengkonsepkan sendiri pengetahuannya melalui pembelajaran yang dilakukan (Fadilah et al., 2017; Waseso, 2018). Salah satu pembelajaran yang berlandaskan pendekatan konduktivitas adalah pembelajaran contextual. Dalam pembelajaran kontekstual, kompetensi yang ditekankan adalah pengembangan pemahaman, penerapan, dan menganalisis pengetahuan faktual, konseptual, prosedural dan metakognitif berdasarkan rasa ingin tahu tentang ilmu pengetahuan penyebab fenomena kejadian dan menerapkan pengetahuan prosedural pada bidang kajian yang spesifik sesuai dengan bakat dan minatnya untuk memecahkan masalah (Adirakasiwi et 
al., 2018). Umumnya masalah yang sering dihadapi oleh mahasiswa pada saat proses perkuliahan berlangsung adalah kurang fasih dalam mengemukakan gagasan, mahasiswa kurang aktif dalam proses pembelajaran, dan rendahnya hasil belajar mahasiswa. Hasil belajar untuk 2 tahun terakhir mahasiswa program studi pendidikan biologi semester 2 Universitas Flores disajikan pada Tabel 1.

Tabel 1. Persentase Hasil Belajar Kimia 2 Tahun Terakhir

\begin{tabular}{ccc}
\hline Nilai & $\mathbf{2 0 1 8} / \mathbf{2 0 1 9}$ & $\mathbf{2 0 1 9 / 2 0 2 0}$ \\
\hline A & - & $10 \%$ \\
B & $49,67 \%$ & $52 \%$ \\
C & $47,67 \%$ & $34 \%$ \\
D & $2,66 \%$ & $4 \%$ \\
E & - & - \\
\hline
\end{tabular}

Hasil observasi selama pembelajaran berlangsung ternyata: 1) kurang adanya variasi dalam penggunaan model pembelajaran sehingga mengakibatkan kejenuhan dengan proses belajar mengajar; 2) mahasiswa pada saat mengikuti perkuliahan sering mengalami kesulitan dalam penguasaan konsep, khususnya dalam hal membedakan larutan. Jika masalah ini dibiarkan akan berdampak materi-materi yang lebih kompleks. Sehingga untuk mengatasi hal tersebut maka dibutuhkan sebuah model pembelajaran yang membuat mahasiswa belajar aktif menemukan dan membangun pengetahuannya. Salah satu model yang bisa melibatkan siswa secara penuh dalam proses pembelajaran adalah model pembelajaran berdasarkan masalah.

Model pembelajaran berdasarkan masalah adalah model pembelajaran yang didesain sesuai dengan masalah nyata dalam kehidupan sehari-hari, yang bersifat tidak terstruktur dan terbuka (Made et al., 2013; Santoso, 2018; Silaban et al., 2019). Pemberian masalah yang berhubungan langsung dengan kehidupan sehari-hari mahasiswa akan memberikan kesempatan kepada mahasiswa untuk lebih mudah menguasai materi dan akan menumbuhkan rasa ingin tahu dan mahasiswa akan lebih termotivasi dalam belajar, (Fitriani, 2017; Kurniawan \& Wuryandani, 2017). Selain dapat menumbuhkan motivasi belajar, pembelajaran berdasarkan masalah akan mengembangkan kemampuan berpikir kritis, karena siswa dirangsang untuk memecahkan masalah dengan kemampuannya sendiri menghubungkan konsep yang dia sudah punya dan dihubungkan dengan konsep yang dia temukan (Haryanti, 2017; Qomariyah, 2016). Kelebihan dari model pembelajaran berbasis masalah adalah menggunakan permasalahan yang ada dalam kehidupan sehari-hari dan harus dipecahkan oleh siswa. Oleh karena itu, dengan penerapan pembelajaran berbasis masalah diharapkan kemampuan pemecahan masalah pada siswa dapat meningkat (Siswantoro, 2018). Sintaks atau tahapan dari model pembelajaran berbasis masalah Arends (Ashari \& Salwah, 2017) adalah sebagai berikut fase 1 memberikan orientasi tentang permasalahan kepada mahasiswa, fase 2 mengorganisasi mahasiswa untuk meneliti atau memahami masalah dan merencanakan penyelesaiannya, fase 3 membantu investigasi mandiri atau kelompok, fase 4 mengembangkan dan mempresentasikan model solusi dan penyajian dan fase 5 menganalisis dan mengevaluasi proses penyelesaian masalah.

Beberapa penelitian yang sudah dilakukan yang berkaitan tentang pembelajaran sberdasarkan masalah, antara lain penelitian yang dilakukan oleh Hendra Prasetia \& Muhari (2019) terdapat pengaruh yang signifikan pembelajaran berbasis masalah, terhadap pemahaman siswa akan hak dan kewajiban siswa sekolah dasar sebagai warga negara. Apriyanto et al., (2017) hasil penelitian menyatakan guru mata pelajaran IPS geografi dalam pembelajaran geografi perlu dilakukan dengan menggunakan model pembelajaran berbasis masalah karena ini sangat mendukung untuk kemampuan berfikir kritis serta meningkatkan kecerdasan dan hasil belajar. Penelitian Baiq Ewik Jiniarti, Ahmad Harjono (2019) tentang pengembangan perangkatan pembelajaran berbasis masalah perbantuan virtual eksperimen untuk meningkatkan penguasaan konsep peserta didik pada materi alat-alat optik. Pada penelitian ini hanya menekankan pada pengembangan perangkat untuk penguasaan konsep peserta didik SMA kelas XI, sedangkan penelitian lebih fokus pada penguasaan konsep mahasiswa pada mata kuliah kimia materi larutan. Penelitian Kurniawan \& Wuryandani (2017) menemukan bahwa Temuan menunjukkan bahwa pembelajaran berbasis masalah (kelas eksperimen) lebih baik daripada expository (kelas kontrol) terhadap pemahaman dalam pembelajaran matematika ekonomi. Tidak hanya itu, mahasiswa dalam kelompok eksperimen menunjukkan sikap yang positif terhadap pembelajaran matematika ekonomi. Penelitian Nurliani et al. (2016) menyatakan bahwa Pembelajaran dengan model pembelajaran berbasis masalah lebih baik dibandingkan model pembelajaran konvensional. Hal ini terbukti dari hasil perhitungan uji rata-rata 
perhitungan n-gain kelas eksperimen yang memperoleh nilai 0,70 dan rata-rata perhitungan n-gain kelas kontol yang memperoleh nilai 0,60. Jadi, dapat dikatakan bahwa dengan adanya model pembelajaran berdasarkan masalah mampu berdampak positif terhadap kemampuan siswa, motivasi serta kemampuan berpikir kritis serta berdampak terhadap pemahaman konsep.

Berdasarkan kelebihan model PBM dan penelitian relevan maka dirumuskan sebuah tujuan penelitian yaitu marginalizes pengembangan pembelajaran berdasarkan masalah pada mata kuliah kimia untuk meningkatkan penguasaan konsep mahasiswa. Dengan penerapan model ini, maka diharapkan mampu mengatasi masalah penguasaan konsep materi yang diberikan yang akan berdampak pada hasil belajar. Karena dengan adanya model ini mahasiswa akan belajar lebih aktif dan termotivasi dalam belajar sehingga siswa akan mengikuti pembelajaran dengan baik dan hasil yang diinginkan akan dapat di wujudkan.

\section{Metode}

Penelitian ini merupakan penelitian pengembangan, yaitu suatu penelitian yang tidak dilakukan randominasi untuk mengelompokkan subjek ke dalam kelompok eksperimen dan kelompok kontrol, melainkan menggunakan kelompok subjek yang sudah ada sebelumnya. Penelitian ini dilaksanakan dari bulan April-Juni 2020, dengan mahasiswa semester 2 program studi pendidikan biologi Universitas Flores yang berjumlah 20 orang sebagai sampelnya. Pengambilan sampel dilakukan secara acak. Adapun instrumen yang digunakan untuk mengumpulkan data dalam penelitian ini adalah tes penguasaan konsep. Instrumen tes ini digunakan untuk mendapatkan data tentang penguasaan konsep mahasiswa sebelum dan sesudah implementasi model pembelajaran berdasarkan masalah. Bentuk tes yang diberikan berupa pilihan ganda mata kuliah kimia, khusunya materi larutan, baik pada pretest dengan jumlah soal 20 nomor maupun posttest dengan jumlah soal sesuai dengan tujuan pembelajaran yang telah dibuat. Pretest diberikan pada saat sebelum pembelajaran dimulai baik pada kelas eksperimen maupun pada kelas kontrol, sedangkan posttest digunakan untuk mengukur penguasaan konsep mahasiswa setelah pembelajaran pada kelas eksperimen dan pada kelas kontrol. Indikator instrumen tes penguasaan konsep mahasiswa pada mata kuliah kimia merujuk pada 1). C1= mengingat, 2) C2= memahami, 3) C3= mengaplikasikan 4) C4= menganalisis, dan 5) C5= mengevaluasi (Yustiqvar, dkk., 2019). Untuk mendapatkan data yang valid maka diperlukan instrumen yang valid dan reliabel sehingga instrumen tes penguasaan konsep dianalisis dengan menggunakan rumus korelasi pearson product moment, sedangkan untuk mengetahui tingkat keterhandalan instrumen agar dapat dipercaya, maka instrumen tersebut diuji dengan menggunakan rumus KR-21. Teknik analisis data untuk penguasaan konsep dilakukan secara statistik. Hal ini dilakukan untuk mengetahui bahwa pengembangan model pembelajaran berdasarkan masalah yang diberikan dapat meningkatkan penguasaan konsep mahasiswa daripada sebelum penggunaan model pembelajaran berdasarkan masalah, sehingga penganalisisan data pada penelitian ini dengan melakukan uji normalitas, uji homogenitas, dan uji-t.

\section{Hasil dan pembahasan}

Penelitian ini dilakukan Universitas Florespada materi larutan, dimana penelitian bertujuan untuk mengembangkan pembelajaran berdasarkan masalah pada mata kuliah Kimia. Penelitian ini dilakukan menggunakan model pembelajaran berdasarkan masalah yang makna proses pengumpulan data dilakukan dengan metode pemberian tes yang sebelumnya sudah dilakukan pengujian. Data yang dikumpulkan di analysis dengan uji t namun sebelum dilakukan pengujian hipotesis maka dilakukan uji normalitas dan uji homogenitas.

Uji normalitas digunakan untuk mengetahui apakah sebaran data penguasaan konsep mahasiswa pendidikan biologi semester 2 Universitas Flores pada materi larutan di kelas kontrol dan kelas eksperimen berdistribusi normal atau tidak. Pada uji ini, hasil signifikansi $>0,05$ dengan dianalisis menggunakan Kolmogorov-Smirnov. Data hasil uji nomalitas dapat dilihat pada tabel 6. 
Tabel 2. Hasil Uji Normalitas

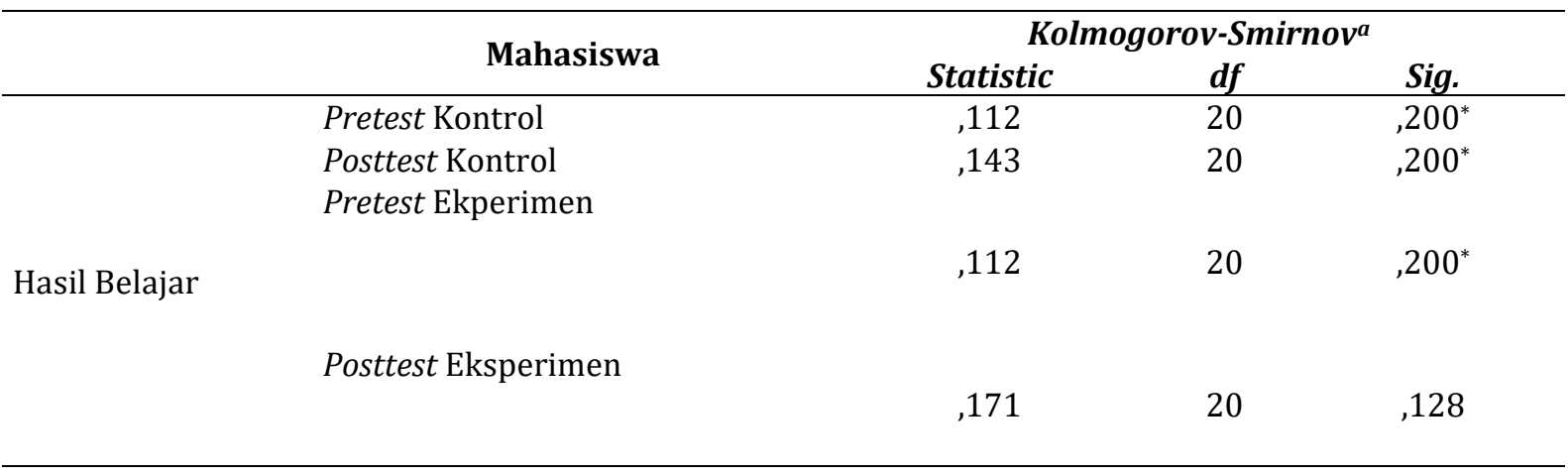

Dari hasil uji normalitas pada tabel 2, diketahui bahwa nilai normalitas penguasaan konsep pada kelas kontrol, baik nilai pretest maupun posttest $>0,05$, yakni 0,200. Pada kelas eksperimen, nilai nomalitas penguasaan konsep baik pretest dan posttest juga $>0,05$, yakni untuk pretest sebesar 0,200 dan untuk posttest sebesar 0,128 . Hal tersebut menunjukkan bahwa sebaran data penguasaan konsep berdistribusi normal, sehingga pengujian selanjutnya bisa dilakukan. Hasil belajar mahasiswa dianalisis sama tidaknya variansi distribusi kelas eksperimen dan kontrol menggunakan uji homogenitas. Dilihat nilai uji homogenitas varian hasil belajar mahasiswa $>0,05$. Nilai uji homogenitas ini ditunjukkan dari nilai signifikansi, yaitu sebesar 0,332. Besarnya nilai signifikansi >0,05 menunjukkan bahwa variansi hasil belajar mahasiswa pada materi larutan adalah homogen (Ilham Handika, 2013).

Dari hasil uji normalitas dan homogenitas, diketahui bahwa hasil belajar mahasiswa baik pretest maupun posttest terdistribusi normal dan variansi antarkelompok sama, sehingga bisa dilanjutkan ke uji-t. Uji-t digunakan untuk menjawab hipotesis, apakah pengembangan pembelajaran berdasarkan masalah dapat meningkatkan penguasaan konsep mahasiswa pada materi larutan. Untuk menjawab permasalahan dalam penelitian ini, maka ditarik hipotesis seperti yang ditampilkan pada tabel 8.

Tabel 3 . Uji Paired Sample Test

\begin{tabular}{|c|c|c|c|c|c|c|c|c|}
\hline & \multicolumn{5}{|c|}{ Paired Differences } & \multirow[t]{3}{*}{$t$} & \multirow[t]{3}{*}{$d f$} & \multirow{3}{*}{$\begin{array}{l}\text { Sig. (2- } \\
\text { tailed) }\end{array}$} \\
\hline & \multirow[t]{2}{*}{ Mean } & \multirow[t]{2}{*}{$\begin{array}{c}\text { Std. } \\
\text { Deviation }\end{array}$} & \multirow[t]{2}{*}{$\begin{array}{c}\text { Std. } \\
\text { Error } \\
\text { Mean }\end{array}$} & \multicolumn{2}{|c|}{$\begin{array}{l}\text { 95\% Confidence } \\
\text { Interval of the } \\
\text { Difference }\end{array}$} & & & \\
\hline & & & & Lower & Upper & & & \\
\hline $\begin{array}{l}\text { Pretest } \quad \text { Kontrol-Posttest } \\
\text { Kontrol }\end{array}$ & $-4,450$ & 2,856 & ,639 & $-5,787$ & $-3,113$ & $-6,969$ & 19 & ,000 \\
\hline $\begin{array}{l}\text { Pretest Eksperimen- } \\
\text { Posttest Eksperimen }\end{array}$ & $-5,850$ & 3,048 & ,682 & $-7,277$ & $-4,423$ & $-8,582$ & 19 & ,000 \\
\hline
\end{tabular}

Berdasarkan hasil penelitian yang diperoleh, maka dengan penerapan model pembelajaran berdasarkan malah berdampak positif terhadap pemahaman konsep mahasiswa. Model berdasarkan masalah adalah salah satu model pembelajaran berdasarkan pendekatan koktruktivistik. Dimana mahasiswa menggali dan membangun pengetahuannya sendiri. Model pembelajaran berdasarkan masalah adalah model pembelajaran yang didesain sesuai dengan masalah nyata dalam kehidupan sehari-hari, yang bersifat tidak terstruktur dan terbuka (Made et al., 2013; Mastika Yasa \& Bhoke, 2019; Santoso, 2018; Silaban et al., 2019). Pemberian masalah yang kontekstual akan membuat siswa lebih mudah dalam mencarikan solusi karena mereka sudah memahami masalah yang diberikan, dan tentunya ini akan berdampak terhadap keinginan untuk menyelesaikan masalah yang diberikan. Jika masalah itu sangat abstrak dan bersifat tidak kontekstual akan menimbulkan rasa frustasi dalam menyelesaikannya dan ini akan menimbulkan ketidakinginan dalam menyelesaikan masalah yang diberikan. Sari \& Sugiyarto (2015) menyatakan bahwa masalah nyata yang diberikan dalam proses pembelajaran akan meningkatkan motivasi belajar siswa. Dengan adanya motivasi belajar siswa akan lebih mudah menerima dan membangun pemahaman akan konsep yang ditemukan baik dari proses kajian pustaka ataupun diskusi dengan kelompoknya. 
Pembelajaran berdasarkan masalah dikaitkan dengan masalah nyata kehidupan sehari-hari, sehingga menuntut perspektif majemuk (multiple perspective) mahasiswa (M. Dewi Kartika, W. Santyasa, 2014; Rusman, 2014). Perspektif majemuk pada PBM diawali dengan belajar membahas masalah autentik yang berhubungan dengan materi larutan. PBM merangsang mahasiswa untuk mendapatkan konsepkonsep pada pokok bahasan sebelumnya dalam mata kuliah kimia. Selain itu, pembelajaran berdasarkan masalah juga memotivasi mahasiswa sehingga merasa tertantang untuk mendapatkan pembelajaran di rana pembelajaran yang baru. Pembelajaran PBM membentuk mahasiswa untuk memiliki pengetahuan memecahkan masalah, agar dapat berpikir kritis, analitis, sistematis, dan logis dalam memilih bentuk pemecahan masalah. Hasil penelitian sebelumnya yang mendukung penelitian ini yakni Handayani \& Yanti (2017); Nurul Ihsani (2020); Suparni (2017) menyatakan bahwa model pembelajaran berdasarkan masalah dapat meningkatkan penguasaan konsep. Pernyataan ini juga didukung penelitian terdahulu maka dengan menggunakan PBM, mahasiswa dilatih untuk belajar mandiri, kolaboratif, komunikatif dan kooperatif, serta memanfaatkan sumber pengetahuan yang bervariasi tidak dari satu sumber saja, sehingga dapat bekerja secara kelompok, saling berinteraksi, saling mengajarkan (peer teaching) dan presentasi (Jauhari, 2016; Latifah, 2020). Jadi, dapat dikatakan bahwa dengan adanya model ini maka siswa akan dituntut untuk menghubungkan pengetahuan yang sudah dia miliki dengan pengetahuan yang dia dapatkan.

Penerapan model pembelajaran berdasarkan masalah dapat meningkatkan kemampuan berpikir kritis siswa hal ini disebabkan oleh pada sintaks model pembelajarannya siswa memecahkan masalah dengan melakukan sebuah proses pengumpulan data baik dengan bukau ataupun percobaan hal ini secara tidak langsung merangsang kemampuan siswa untuk tidak menerima jawaban dari teman begitu saja. Kemampuan berpikir kritis adalah kemampuan untuk menganalisis dan mengevaluasi masalah yang diperoleh sehingga diperoleh sebuah kesimpulan (Nuryanti et al., 2018; Saleh, 2019). Berpikir kritis dapat dikembangkan dari sintaks model pembelajaran berdasarkan masalah. Sintaks atau tahapan dari model pembelajaran berbasis masalah Arends (Ashari \& Salwah, 2017) adalah sebagai berikut fase 1 memberikan orientasi tentang permasalahan kepada mahasiswa, fase 2 mengorganisasi mahasiswa untuk meneliti atau memahami masalah dan merencanakan penyelesaiannya, fase 3 membantu investigasi mandiri atau kelompok, fase 4 mengembangkan dan mempresentasikan model solusi dan penyajian dan fase 5 menganalisis dan mengevaluasi proses penyelesaian masalah. Jadi dapat dikatakan dengan sintaks model yang ada, kemampuan berpikir kritis siswa dapat meningkat.

Penerapan model pembelajaran dapat meningkatkan interaksi antara siswa dengan teman akan berkembang dengan baik, karena mahasiswa akan berkerja sama dengan kelompoknya untuk menghasilkan sebuah pemecahan masalah yang diberikan. Adanya interaksi antar mahasiswa akan mempengaruhi hasil belajar mahasiswa. Interaksi yang baik antar siswa akan membuat suasana pembelajaran lebih nyaman dan tentunya hal ini akan mempengaruhi kemampuan siswa belajar, karena mahasiswa akan lebih mudah belajar dengan teman sebayanya. Mujiastuti \& Ilyasir (2016) menyatakan bahwa teman sebaya mempunyai dampak yang positif dan dampak yang negative. Denanti \& Wardani (2020) menyatakan bahwa adanya interaksi antar siswa dapat berdampak pada proses pembelajaran. sedangkan Syahrudin (2019) menyatakan bahwa afiksasi diri dan teman sebaya berpengaruh terhadap prestasi belajar. Jadi, dapat dikatakan bahwa dengan adanya interaksi yang baik akan menghasilkan sebuah pemahaman yang nantinya akan berdampak terhadap hasil belajar

Beberapa penelitian yang sudah dilakukan yang berkaitan tentang pembelajaran berdasarkan masalah, antara lain penelitian yang dilakukan oleh Hendra Prasetia \& Muhari (2019) terdapat pengaruh yang signifikan pembelajaran berbasis masalah, terhadap pemahaman siswa akan hak dan kewajiban siswa sekolah dasar sebagai warga negara. Apriyanto et al. (2017) hasil penelitiannya mencatatkan guru mata pelajaran IPS geografi dalam pembelajaran geografi perlu dilakukan dengan menggunakan model pembelajaran berbasis masalah karena ini sangat mendukung untuk kemampuan berfikir kritis serta meningkatkan kecerdasan dan hasil belajar. Penelitian Baiq Ewik Jiniarti \& Ahmad Harjono (2019) tentang pengembangan perangkatan pembelajaran berbasis masalah perbantuan virtual eksperimen untuk meningkatkan penguasaan konsep peserta didik pada materi alat-alat optik. Pada penelitian ini hanya menekankan pada pengembangan perangkat untuk penguasaan konsep peserta didik SMA kelas XI, sedangkan penelitian lebih fokus pada penguasaan konsep mahasiswa pada mata kuliah kimia materi larutan. Penelitian Kurniawan \& Wuryandani (2017) menemukan bahwa Temuan menunjukkan bahwa pembelajaran berbasis masalah (kelas eksperimen) lebih baik daripada expository (kelas kontrol) terhadap pemahaman dalam pembelajaran matematika ekonomi. Tidak hanya itu, mahasiswa dalam kelompok eksperimen menunjukkan sikap yang positif terhadap pembelajaran matematika ekonomi. Penelitian Nurliani et al. (2016) menyatakan bahwa Pembelajaran dengan model pembelajaran berbasis masalah lebih baik dibandingkan model pembelajaran konvensional. Hal ini terbukti dari hasil perhitungan uji rata-rata perhitungan n-gain kelas eksperimen yang memperoleh nilai 0,70 dan rata-rata perhitungan n-gain kelas 
kontol yang memperoleh nilai 0,60. Jadi, dapat dikatakan bahwa dengan adanya model pembelajaran berdasarkan masalah mampu berdampak positif terhadap kemampuan siswa, motivasi serta kemampuan berpikir kritis serta berdampak terhadap pemahaman konsep.

Berdasarkan jabaran hasil dan pembahasan dapat dikatakan bahwa penerapan model pembelajaran berdasarkan masalah memberikan dampak yang positif terhadap pemahaman konsep. Pemahaman konsep adalah sebuah kemampuan yang dimiliki oleh mahasiswa yang berkaitan dengan memahami materi yang diberikan hal, pemahaman konsep bukan hanya sekedar menghafal bela (Fahrudin et al., 2018). Kemampuan pemahaman konsep ini berkembang dengan optimal karena model pembelajaran berdasarkan masalah membuat mahasiswa secara aktif mengikuti pembelajaran dan membangun pengetahuannya sendiri karena dalam proses pembelajaran mahasiswa secara mandiri mencari dan memecahkan masalah yang diberikan. Dengan kondisi demikian membuat mahasiswa mempunyai pengetahuan yang kompleks.

\section{Simpulan dan saran}

Pengembangan pembelajaran berdasarkan masalah dapat meningkatkan penguasaan konsep mahasiswa Program Studi Pendidikan Biologi Semester 2 Fakultas Keguruan dan Ilmu Pendidikan Universitas Flores pada mata kuliah kimia materi larutan.

\section{Daftar Rujukan}

Adirakasiwi, A. G., Warmi, A., \& Imami, A. I. (2018). Penerapan Pendekatan Kontekstual Terhadap Penguasaan Konsep Dasar Materi Volume Benda Putar. Jurnal Penelitian Dan Pembelajaran Matematika, 11(1), 1-10. https://doi.org/10.30870/jppm.v11i1.3005

Apriyanto, B., Nurdin, E. A., Ikhsan, F. A., \& Kurniawan, F. A. (2017). Penerapan Pembelajaran Berbasis Masalah Untuk Meningkatkan Aktivitas Dan Hasil Belajar Siswa Dalam Memahami Lingkungan Hidup Pada Mata Pelajaran Ips Di Smp Negeri 2 Sukodono. JURNAL PENDIDIKAN EKONOMI: Jurnal Ilmiah Ilmu Pendidikan, Ilmu Ekonomi Dan Ilmu Sosial, 11(2), 7. https://doi.org/10.19184/jpe.v11i2.5727

Ashari, N. W., \& Salwah, S. (2017). Problem Based Learning (PBL) dalam Meningkatkan Kecakapan Pembuktian Matematis Mahasiswa Calon Guru. JMPM: Jurnal Matematika Dan Pendidikan Matematika, 2(2), 100. https://doi.org/10.26594/jmpm.v2i2.891

Baiq Ewik Jiniarti, Ahmad Harjono, M. M. (2019). Pengembangan Perangkat Model Pembelajaran Berbasis Masalah Berbantuan Virtual Eksperimen untuk Meningkatkan Penguasaan Konsep Peserta Didik pada Materi Alat-Alat Optik. Pijar MIPA, 14(2), 25-30. https://doi.org/DOI: 10.29303/jpm.v14i2.1233

Denanti, I. A., \& Wardani, S. Y. (2020). Pengaruh komunikasi interpersonal dan interaksi teman sebaya terhadap kepercayaan diri dalam berpendapat. ... Seminar Nasional Bimbingan Dan ..., 3(1), 111-118. http://prosiding.unipma.ac.id/index.php/SNBK/article/view/1412

Fadilah, S. I., Kardi, S., \& Supardi, Z. A. I. (2017). Pengembangan Perangkat Pembelajaran Biologi Berbasis Inkuiri Materi Sistem Ekskresi Manusia Untuk Melatih Keterampilan Berpikir Kritis Dan Kerjasama Siswa Sma. JPPS (Jurnal Penelitian Pendidikan Sains), $5(1), \quad 779$. https://doi.org/10.26740/jpps.v5n1.p779-787

Fahrudin, A. G., Zuliana, E., \& Bintoro, H. S. (2018). Peningkatan Pemahaman Konsep Matematika melalui Realistic Mathematic Education Berbantu Alat Peraga Bongpas. ANARGYA: Jurnal Ilmiah Pendidikan Matematika, 1(1), 14-20. https://doi.org/10.24176/anargya.v1i1.2280

Fitriani, M. (2017). Pengaruh Model PBL Terhadap Motivasi Belajar Sistem Koordinasi pada Siswa di SMA Negeri Bantaeng. Biotek, 5(1), 228-239.

Handayani, R. D., \& Yanti, Y. (2017). PENGARUH MODEL PEMBELAJARAN KOOPERATIF TIPE THINK PAIR SHARE TERHADAP HASIL BELAJAR PKn SISWA DI KELAS IV MI TERPADU MUHAMMADIYAH SUKARAME BANDAR LAMPUNG. Jurnal Pendidikan Dan Pembelajaran Dasar, 4(2), 107-123.

Haryanti, Y. D. (2017). Model Problem Based Learning Membangun Kemampuan Berpikir Kritis Siswa Sekolah Dasar. Jurnal Cakrawala Pendas, 3(2). https://doi.org/10.31949/jcp.v3i2.596 
Hendra Prasetia, Muhari, W. T. S. (2019). Pengaruh Pembelajaran Berbasis Masalah Terhadap Pemahaman Siswa Mengenai Hak dan Kewajiban Siswa Sekolah Dasar Sebagai Warga Negara. Jurnal Review Pendidikan Dasar: Jurnal Kajian Pendidikan Dan Hasil Penelitian, 5(2). https://doi.org/http://dx.doi.org/10.26740/jrpd.v5n2.p967-975

Hidayat, T., \& Syafe'i, M. (2018). Peran Guru Dalam Mewujudkan Tujuan Pembelajaran Pendidikan Agama Islam Di Sekolah. Rayah Al-Islam, 2(01), 101-111. https://doi.org/10.37274/rais.v2i01.67

Ilham Handika, M. N. W. (2013). Pengaruh Pembelajaran Berbasis Masalah Terhadap Penguasaan Konsep dan Keterampilan Proses Sains Siswa Kelas V. Jurnal Prima Edukasia, Volume, I(2), 85-93. https://doi.org/https://doi.org/10.21831/jpe.v1i1.2320

Jauhari, T. (2016). Pengaruh Model Pembelajaran Berbasis Masalah Berbantuan Media Phet Terhadap Hasil Belajar Fisika Siswa Kelas X SMAN 1 Gunungsari Tahun Pelajaran 2015 / 2016. Jurnal Pendidikan Fisika Dan Teknologi, II(1), 7-12. http://jurnalfkip.unram.ac.id/index.php/JPFT/article/view/282

Kurniawan, M. W., \& Wuryandani, W. (2017). Pengaruh model pembelajaran berbasis masalah terhadap motivasi belajar dan hasil belajar PPKn. Jurnal Civics: Media Kajian Kewarganegaraan, 14(1), 10-22. https://doi.org/10.21831/civics.v14i1.14558

Latifah, A. Z. (2020). Penerapan Metode Mind Mapping untuk Meningkatkan Kreativitas pada Pembelajaran Pendidikan Kewarganegaraan. Jurnal Pendidikan, 21(1).

M. Dewi Kartika, W. Santyasa, W. W. (2014). Pengaruh Model Pembelajaran Berbasis Masalah Terhadap Pemahaman Konsep Fisika Dan Keterampilan Berpikir Kritis Siswa. E-Journal Program Pascasarjana Universitas Pendidikan Ganesha, 4(1). https://media.neliti.com/media/publications/207142pengaruh-model-pembelajaran-berbasis-mas.pdf

Made, G., Sudarman, C., Haris, I. A., Nuridja, I. M., Ekonomi, P., \& Ekonomi, F. (2013). Penerapan Model Pembelajaran Berbasis Masalah ( Problem-Based Learning) Untuk Meningkatkan Aktivitas Dan Hasil Belajar Siswa Pada Mata Pelajaran Ekonomi Siswa Kelas X1 Sma Negeri 1 Sawan Tahun 2012 / 2013. Jurnal Pendidikan Ekonomi Undiksha, 2(1). https://doi.org/http://dx.doi.org/10.23887/jjpe.v2i1.807

Mastika Yasa, P. A. E., \& Bhoke, W. (2019). Pengaruh Model Problem Based Learning Terhadap Hasil Belajar Matematika Pada Siswa Sd. Journal of Education Technology, 2(2), 70. https://doi.org/10.23887/jet.v2i2.16184

Mujiastuti, A. I. C., \& Ilyasir, F. (2016). Pengaruh Pertemanan Sebaya Terhadap Prestasi Belajar Pendidikan Agama Islam Siswa Kelas Xi Sma Negeri 1 Sewon, Bantul Tahun Pelajaran 2013/2014. LITERASI (Jurnal Ilmu Pendidikan), 6(1), 77. https://doi.org/10.21927/literasi.2015.6(1).77-97

Nurliani, N., Subarjah, H., \& Sujana, A. (2016). Pengaruh Model Pembelajaran Berbasis Masalah Terhadap Hasil Belajar Peserta Didik Pada Materi Peristiwa Alam. Pengaruh Model Pembelajaran Berbasis Masalah Terhadap Hasil Belajar Peserta Didik Pada Materi Peristiwa Alam, 1(1), 981-990. https://doi.org/10.23819/pi.v1i1.3009

Nurul Ihsani, A. A. I. J. J. (2020). Pengembangan Perangkat Pembelajaran Matematika Berorientasi Model Pembelajaran Berbasis Masalah (PBM) Untuk Meningkatkan Kemampuan Berpikir Kritis Siswa SMA Se Kuala Nagan Raya Aceh. Pijar MIPA, 15(2), 103-109. https://doi.org/10.29303/jpm.v15i2.1326

Nuryanti, L., Zubaidah, S., \& Diantoro, M. (2018). Analisis Kemampuan Berpikir Kritis Siswa SMP. Jurnal Pendidikan: Teori, Penelitian, Dan Pengembangan, 3(2), 155-158. https://doi.org/10.17977/JPTPP.V3I2.10490

Qomariyah, E. N. (2016). Pengaruh Problem Based Learning terhadap Kemampuan Berpikir Kritis IPS. Jurnal Pendidikan Dan Pembelajaran, 23(2), 132-141.

Rusman. (2014). Penerapan Pembelajaran Berbasis Masalah. Edutech, 13(2), 211. https://doi.org/10.17509/edutech.v13i2.3102

Saleh, S. (2019). Analisis Kemampuan Berpikir Kritis Siswa dalam Pembelajaran Biologi. Florea, 6(1), 4553. https://doi.org/http://doi.org/10.25273/florea.v6i1.4369

Santoso, E. (2018). Pembelajaran Berbasis Masalah dalam Upaya Meningkatkan Kemampuan Pemahaman Matematik Siswa. Jurnal THEOREMS (The Original Research of Mathematics), 2(2), 80-87. https://www.jurnal.unma.ac.id/index.php/th/article/view/723 
Sari, D. S., \& Sugiyarto, K. H. (2015). Pengembangan Multimedia Berbasis Masalah Untuk Meningkatkan Motivasi Belajar Dan Kemampuan Berpikir Kritis Siswa. Jurnal Inovasi Pendidikan IPA, 1(2), 153. https://doi.org/10.21831/jipi.v1i2.7501

Silaban, T., Lubis, R., \& Ahmad, M. (2019). EFEKTIVITAS MODEL PEMBELAJARAN BERBASIS MASALAH ( PBM ) TERHADAP KEMAMPUAN BERPIKIR KREATIF MATEMATIS SISWA SMP NEGERI 1 PINANGSORI Oleh: JURNAL MathEdu (Mathematic Education Journal), 2(3), 103-108. http://journal.ipts.ac.id/index.php/MathEdu/article/view/1024/601

Suparni, S. (2017). Meningkatkan Hasil Belajar Siswa Dengan Pembelajaran Berbasis Masalah. JPPI (Jurnal Penelitian Pendidikan Indonesia), 3(1), 36. https://doi.org/10.29210/02017107

Syahrudin. (2019). Pengaruh efikasi diri dan dukungan sosial teman sebaya terhadap prestasi belajar. Cognicia, 7(4), 507-526. https://doi.org/10.30822/asimtot.v1i1.100

Waseso, H. P. (2018). Kurikulum 2013 Dalam Prespektif Teori Pembelajaran Konstruktivisme. Ta'lim, 1(1), 59-72. http://e-jurnal.unisda.ac.id/index.php/talim/article/download/632/349 